Article

\title{
Growth and Physiological Adaptation of Salix matsudana Koidz. to Periodic Submergence in the Hydro-Fluctuation Zone of the Three Gorges Dam Reservoir of China
}

\author{
Chaoying Wang ${ }^{(B)}$, Yingzan Xie, Yanyan He, Xiaoxue Li, Wenhang Yang and Changxiao Li * \\ Key Laboratory of Eco-Environments in the Three Gorges Reservoir Region (Ministry of Education), \\ Chongqing Key Laboratory of Plant Ecology and Resources in the Three Gorges Reservoir Region, \\ School of Life Sciences, Southwest University, Chongqing 400715, China; wcy_ing@163.com (C.W.); \\ xieyingzan@126.com (Y.X.); 13102346968@163.com (Y.H.); 1xx0223@email.swu.edu.cn (X.L.); \\ ywh464492693@email.swu.edu.cn (W.Y.) \\ * Correspondence: lichangx@swu.edu.cn; Tel.: +86-23-6825-2365
}

Received: 3 July 2017; Accepted: 2 August 2017; Published: 4 August 2017

\begin{abstract}
Submergence-tolerant trees are essential for vegetation restoration of the hydro-fluctuation zone of the Three Gorges Dam Reservoir (TGDR) area. Thus, it is of great significance to select the submergence-tolerant plant species by conducting in situ studies. To restore degraded riparian vegetation under the circumstances of dynamic impoundment of the TGDR, Salix matsudana Koidz., a flooding-tolerant native tree species, was introduced to conduct an in situ practical study to test its performance in re-vegetating and restoring the hydro-fluctuation zone of the TGDR. Effects of periodic moderate submergence (MS) and deep submergence (DS) on photosynthesis and growth of Salix matsudana Koidz. were investigated after three water cycles compared to a control (i.e., shallow submergence, abbreviated as SS) in order to specifically assess its application prospects in vegetation restoration under such extreme environment. Results showed that net photosynthetic rate $\left(P_{n}\right)$, intrinsic water use efficiency (WUEi) and limiting value of stomata (Ls) of S. matsudana were significantly reduced in DS. However, pigment content had no significant change in all submergence treatments. Diameter at breast height (DBH) and tree height of $S$. matsudana were significantly decreased in both MS and DS when compared to that of SS, respectively. In contrast, the primary branch number of $S$. matsudana was significantly increased as submergence increased. In addition, relative diameter and height growth rates of $S$. matsudana were also reduced under submergence. Considering the sustained growth of this species, S. matsudana saplings are tolerant to long-term periodic submergence and can be applied to the vegetative restoration of the hydro-fluctuation zone of the TGDR region.
\end{abstract}

Keywords: Three Gorges Dam Reservoir; hydro-fluctuation zone; Salix matsudana; growth; photosynthesis

\section{Introduction}

The Three Gorges Dam (TGD) is the largest dam ever built in the world [1], which is located in the upper reaches of the Yangtze River. After its formal impoundment in 2008, the water level fluctuates from $145 \mathrm{~m}$ a.s.l. in summer to $175 \mathrm{~m}$ a.s.l. in winter annually, which formed a huge hydro-fluctuation zone with an area of $350 \mathrm{~km}^{2}$ and a water level fluctuation of $30 \mathrm{~m}[2,3]$. The TGD had totally reversed the submergence season and increased the submergence depth and duration when compared to the original hydrological regime $[4,5]$. This artificial regime has totally changed the habitat of the natural vegetation. Many natural plants die gradually due to intolerance to this great change of their 
habitats [6]. Vegetation degradation of the hydro-fluctuation zone of the Three Gorges Dam Reservoir (TGDR) caused serious degradation of its ecosystem function, resulting in many serious environmental problems [7], such as soil erosion, water pollution, etc. These problems have posed a serious threat to the long-term security operation of the TGDR and need to be solved.

Spontaneous and artificial recovery are two main methods for vegetation restoration [8], which plays an important role in restoring the structure and function of the newly formed riparian ecosystem [9]. Plants, as the principal part of ecosystem function [10], can absorb the pollutions and prevent soil erosion in the TGDR [11-15]. Moreover, they can beautify the environment of the TGDR. Therefore, artificial vegetation restoration was recommended to be used in vegetation restoration of the hydro-fluctuation zone of the TGDR region [16].

In artificial vegetation restoration of the TGDR, many flooding-tolerant plants are needed. Therefore, evaluation of plants for flood tolerance is needed for vegetation restoration of the hydro-fluctuation zone of the TGDR region [17]. In former studies, many suitable plants were selected through experiments that simulated flooding [18-20]. However, the simulated growth condition of these studies differed from the actual situation of the TGDR [5], especially in submergence depth and duration. These great differences may cause the screened plants to die after planting in the hydro-fluctuation zone of the TGDR.

Plant survival in submergence condition is not only associated with the water tolerance of plants, but is also related to plant recovery after submergence. Former studies showed that plants will suffer oxidation from high oxygen and light condition after exposure from submergence with low oxygen and light condition [21-23]. This will cause plant growth decrease or even death [24]. Thus, it is important to consider the recovery stage when assessing flooding-tolerance in plants [25]. Therefore, the aim of this study was to assess plant submergence resistance based on de-submergence recovery under in situ conditions of the TGDR.

Salix spp. is a recommended species for riparian restoration in western countries for its easy propagation from cuttings and rapid growth and wide tolerance to soil flooding [26-28]. Many studies have addressed the tolerance of Salix spp. to flooding [29,30]. In general, Salix spp. have several physiological and morphological characteristics that allow them to endure a variety of water stresses [31]. These changes include controlling of photosynthesis and related gene expression under oxygen deprivation [32,33] and forming adventitious roots [34,35], lenticels and aerenchyma tissues [35] and elongate shoot parts to facilitate aeration of the inundated roots. These morphological adaptations increase the aeration to alleviate oxygen deficiency caused by flooding [26]. Despite having these morphological and physiological adaptations, the growths of Salix spp. were also decreased under flooding [31,35]. However, interspecific differences in flooding tolerance of Salix species were varied. Salix subfragilis L. was more tolerant to flooding than Salix gracilistyla Miq. due to higher root ratio under flooding [36]. Salix viminalis L., with a higher dry mass and greater resprouting capacity, had a higher tolerance to tidal flooding than Salix alba L. [37]. Moreover, Zhong et al. [38] also found that submergence restricted the growth of Salix babylonica L., but it recovered quickly after submergence. Unlike submergence, waterlogging had no significant inhibition on growth and re-growth of this species. Planting study in the Meishan reservoir has shown that Salix matsudana Koidz. can survive and grow well in the hydro-fluctuation zone of the Meishan reservoir [39].

These studies suggest that the interspecific difference in plant growth and metabolism of Salix are related to the intensity of flooding and different species in the same category may respond differently to water stress. However, whether Salix can withstand the long-term deep submergence of the TGDR is not yet clear. The aim of this study was to investigate the application of S. matsudana, a flooding-tolerant native tree species, in artificial vegetation restoration of the hydro-fluctuation zone of the TGDR region. For this purpose, an in situ experiment was conducted to test the recovery of photosynthesis and growth of $S$. matsudana after three-year periodic deep submergence in situ. Based on the performance presented in the literature on Salix species that we studied, we hypothesized that the growth and photosynthesis of $S$. matsudana saplings would recover to control level after such extreme submergence. 


\section{Materials and Methods}

\subsection{Research Site Description}

The experiment was conducted in a S. matsudana plantation with an area of $600 \mathrm{~m}^{2}$ in Ruxi River basin located $32 \mathrm{~km}$ northeast of Zhong County, Chongqing municipality of China $\left(30^{\circ} 24^{\prime} 16^{\prime \prime}-30^{\circ} 24^{\prime} 56^{\prime \prime} \mathrm{N}, 108^{\circ} 08^{\prime} 03^{\prime \prime}-108^{\circ} 08^{\prime} 21^{\prime \prime} \mathrm{E}\right)$. Ruxi River is one of the largest tributaries of the TGDR [40] with subtropical southeast monsoonal climate and average annual temperature of $18.2^{\circ} \mathrm{C}$. Mean annual precipitation is $1200 \mathrm{~mm}$ and relative humidity is $80 \%$. The soil type of the site is purple soil [Regosols in Food and Agriculture Organization (FAO) Taxonomy or Entisols in United States Department of Agriculture (USDA) Taxonomy) [19].

To rehabilitate the vegetation of the hydro-fluctuation zone of the TGDR, an artificial revegetation between $165 \mathrm{~m}$ a.s.l. and $175 \mathrm{~m}$ a.s.l. through reforestation with two-year-old $S$. matsudana saplings was conducted in this site in April 2012. The mean plant height and diameter at breast height (1.3 $\mathrm{m}$ above the ground) of saplings prior to planting were $1.53 \mathrm{~m}$ and $3.00 \mathrm{~mm}$, respectively. After transport from Dajuyuan nursery of Chongqing, 600 saplings were immediately planted in the site with a spacing of $1 \mathrm{~m} \times 1 \mathrm{~m}$ and well-watered once immediately after being planted, and then weeded in mid-June of 2012. After that, there is no watering or weeding any more in the following years. Until measurement, these saplings grew well and experienced three cycles of water level change imposed by the TGDR. The water level change of the TGDR in Zhong County during the experiment was shown in Figure 1. The water level of the reservoir began to gradually rise from $145 \mathrm{~m}$ a.s.l. to $175 \mathrm{~m}$ a.s.l. in late autumn (September-October) each year, and kept the highest water level about two months (November-December). After that period, the water level began to drop gradually from $175 \mathrm{~m}$ a.s.1. to $145 \mathrm{~m}$ a.s.l. over a long time (January-May), and kept the lowest water level to September.

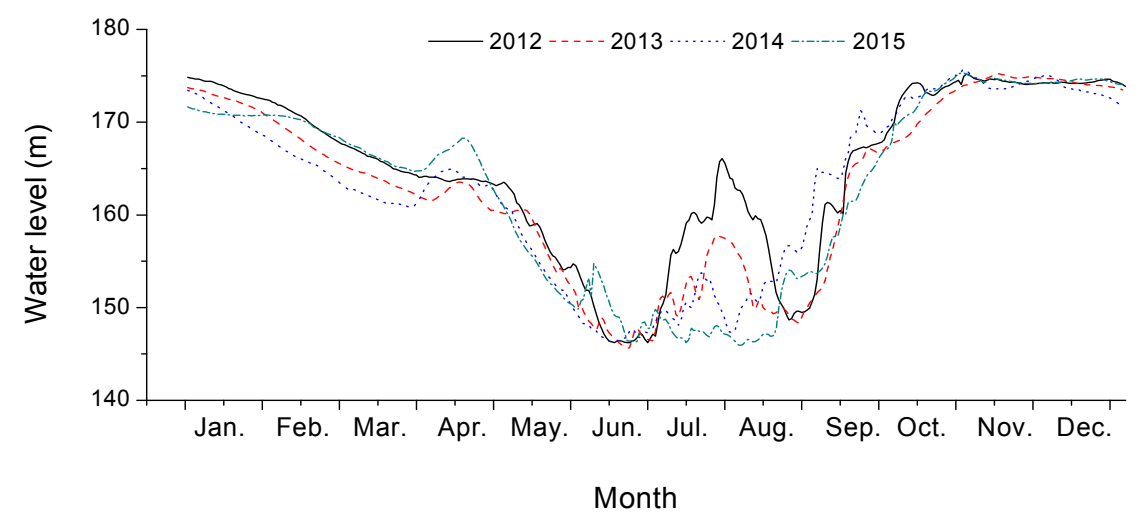

Figure 1. Water level changes of the hydro-fluctuation zone of the Three Gorges Dam Reservoir (TGDR) in Zhong County from January 2012 through December 2015.

\subsection{Experimental Design}

The three submergence treatments of the in situ experiment in the hydro-fluctuation zone of Ruxi River were shallow submergence (SS, serving as control, at the elevation of $175 \mathrm{~m}$ a.s.1.), moderate submergence (MS, at the elevation of $170 \mathrm{~m}$ a.s.1.) and deep submergence (DS, at the elevation of $165 \mathrm{~m}$ a.s.1.). In each treatment, nine representative trees at each elevation were randomly selected and tagged on 12 July 2015 in the middle of their 4th growing season for further testing. Trees located at the edge of the plantation zone were abandoned to avoid the edge effect. The submergence depth and duration of each treatment at different elevation during the three water cycles were measured (Table 1). The submergence depth and duration increased with elevation drop, on the contrary, the exposure duration decreased with elevation drop. The trees had leaves when submerged, and the leaves of the trees were lost during submergence. The trees regenerate the new leaves two weeks later after exposure from the submergence. 
Table 1. Submergence depth and duration of each elevation during the three water cycles of the hydro-fluctuation zone of the TGDR in Zhong County.

\begin{tabular}{ccccc}
\hline \multirow{2}{*}{ Treatment } & $\begin{array}{c}\text { Elevation (Submergence } \\
\text { Depth } \ddagger)(\mathbf{m})\end{array}$ & \multicolumn{2}{c}{ Submergence Duration (Exposure Duration $\$$ ) (day) } \\
\cline { 3 - 5 } & $165(10)$ & $\begin{array}{c}\text { From July 2012 to } \\
\text { June 2013 }\end{array}$ & $\begin{array}{c}\text { From July 2013 to } \\
\text { June 2014 }\end{array}$ & $\begin{array}{c}\text { From July 2014 to } \\
\text { June 2015 }\end{array}$ \\
\hline DS & $170(5)$ & $175(190)$ & $158(207)$ & $217(148)$ \\
MS & $175(0)$ & $125(240)$ & $101(264)$ & $141(224)$ \\
SS & $2(363)$ & $5(360)$ & $8(357)$ \\
\hline
\end{tabular}

$\ddagger$ The submergence depth refers to the water depth above the soil surface in which saplings planted. The submergence depth above the top of the saplings varied due to operation of the TGDR, and can be calculated as the difference between the submergence depth given in this table and the tree height. $\$$ The exposure duration is calculated by the difference between the days of a full year and the days of submergence. DS: deep submergence; MS: moderate submergence; SS: shallow submergence.

\subsection{Measurement of Physiological Responses}

Gas exchange was measured on 12 July 2015 using a portable infrared gas analyzer (Li-6400) with a $6 \mathrm{~cm}^{2}$ leaf chamber and a red/blue light source (Li-Cor, Lincoln, NE, USA). Leaves were induced under saturated light illumination of $1000 \mu \mathrm{mol} \cdot \mathrm{m}^{-2} \cdot \mathrm{s}^{-1}$. The test was conducted between 10:00-15:00 on a fine day [41] with a photosynthetic photon flux density of $1000 \mu \mathrm{mol} \cdot \mathrm{m}^{-2} \cdot \mathrm{s}^{-1}$ and a flow rate of $500 \mu \mathrm{mol} \cdot \mathrm{s}^{-1}$. The $\mathrm{CO}_{2}$ levels during the measurements were not controlled and were $357.4 \pm 0.75 \mu \mathrm{mol} \cdot \mathrm{m}^{-2} \cdot \mathrm{s}^{-1}$ in the cuvette. The fifth to seventh mature and intact leaf located on a branch in the upper canopy was utilized for the measurements of net photosynthetic rate $\left(P_{n}\right)$, stomata conductance $\left(g_{s}\right)$, intercellular $\mathrm{CO}_{2}$ concentration $\left(C_{i}\right)$ and ambient $\mathrm{CO}_{2}$ concentration $\left(C_{a}\right)$. The test leaf was labeled with a marker pen after data recorded, and then rapidly picked and put in cool condition to take to the laboratory. Leaf area in the chamber was measured by WinRHIZO, LC4800-II LA2400. The intrinsic water use efficiency (WUEi) and the limiting value of stomata (Ls) were calculated as $P_{n} / g_{s}$ and $\left(C_{a}-C_{i}\right) / C_{a}$, respectively [42,43]. Chlorophyll a, chlorophyll $\mathrm{b}$ and carotenoid (Car) content of the test leaf was extracted by $80 \%$ acetone in the dark for $72 \mathrm{~h}$ at $4{ }^{\circ} \mathrm{C}$ and measured the absorbance of extracts at 663, 646 and $470 \mathrm{~nm}$ with spectrophotometer UV/VIS 2550 (Shimadzu, Japan) [44]. The chlorophylls (Chls) content and chlorophyll a/b (Chl a/b) were the sum and ratio of chlorophyll a and chlorophyll b.

\subsection{Measurement of Plant Growth}

The measurements on 12 July 2015 included tree height, diameters at breast height $(1.3 \mathrm{~m}$ from the ground) (DBH), crown diameter and primary branch number. A standard meter pole (with an accuracy of $1.0 \mathrm{~cm}$ ) was used to measure the tree height. Vernier caliper was used to measure the DBH of the saplings at two perpendicular directions and the average value was calculated. Measuring tape was used to measure the east-west crown diameter and south-north crown diameter, and the average value was used to calculate the crown area using the formula of area of a circle. Numbers of primary branch with length equal to or greater than $10 \mathrm{~cm}$ on the trunk were recorded. The relative height growth rate (RHGR) and the relative diameter growth rate (RDGR) of saplings during the time period from 1 April 2012 to 12 July 2015 were calculated following the reference of Masaka et al. [45].

\subsection{Data Analysis}

SPSS 16.0 (Chicago, IL, USA) and Microsoft 2007 software were used to analyze the data. One-way ANOVA was used to assess the influence of submergence treatment on growth and photosynthesis of S. matsudana saplings, followed by a Tukey-HSD post hoc test. Correlations between growth and photosynthetic parameters were calculated by Pearson's correlations. 


\section{Results}

\subsection{Gas Exchange Response}

After experiencing three annual cycles of periodic submergence in the hydro-fluctuation zone of the TGDR, the mean $P_{n}$ and WUEi of $S$. matsudana in DS were significantly lower than that in SS ( $p=0.034,0.001$, respectively), with an $18 \%$ and $42 \%$ decrease, respectively, whereas there was no significant difference in $P_{n}$ and WUEi between MS and SS, respectively (both $p>0.05$ ) (Figure 2a,c). The mean $g_{s}$ were not affected by the submergence treatment $(p>0.05)$ (Figure 2b). The mean Ls in DS was significantly lower than that in SS $(p<0.001)$, with a decrease of $35 \%$, while there was no significant difference in Ls between MS and SS ( $p>0.05)$ (Figure 2d).
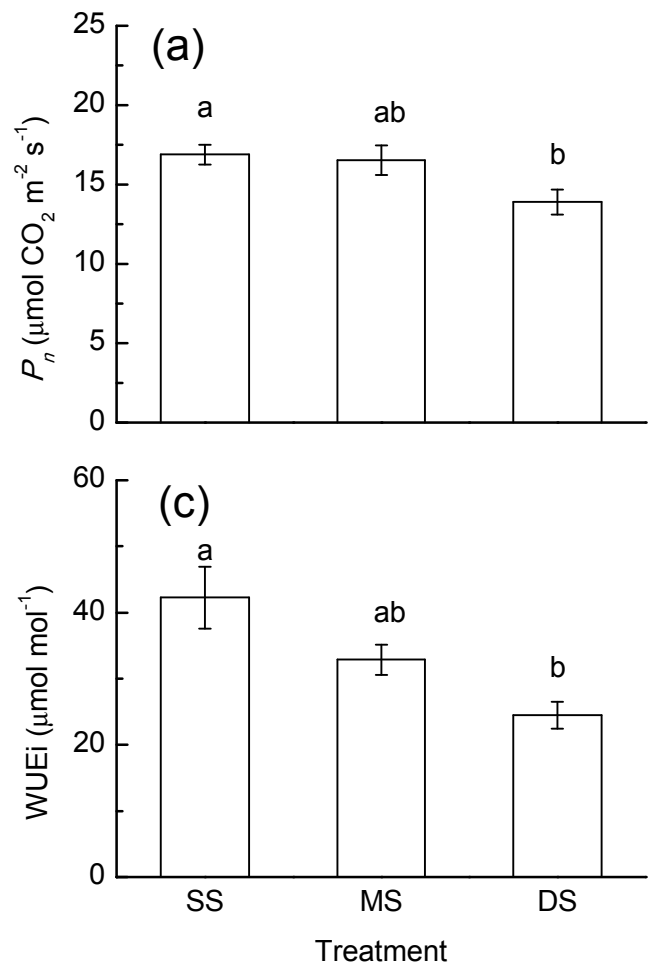
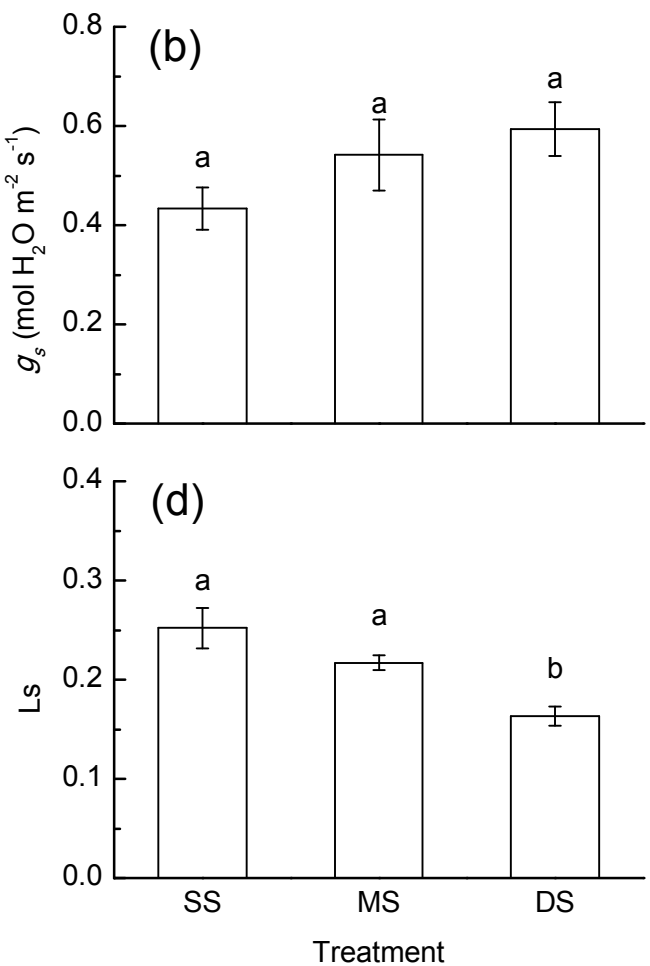

Figure 2. Net photosynthetic rate $\left(P_{n}\right)(\mathbf{a})$, stomata conductance $\left(g_{s}\right)(\mathbf{b})$, intrinsic water use efficiency (WUEi) (c) and limiting value of stomata (Ls) (d) of S. matsudana under shallow submergence (SS), moderate submergence (MS) and deep submergence (DS) treatment in the hydro-fluctuation zone of the TGDR. Different letters on each bar represent significant difference among treatments at the 0.05 level. Values are means \pm standard error $(n=9)$.

\subsection{Pigment Content}

In all saplings, there was no significant difference in content of chlorophylls and carotenoids, ratio of $\mathrm{Chl} \mathrm{a/b}$ and ratio of Chls/Car among the three treatments (all $p>0.05$ ) (Figure 3). 

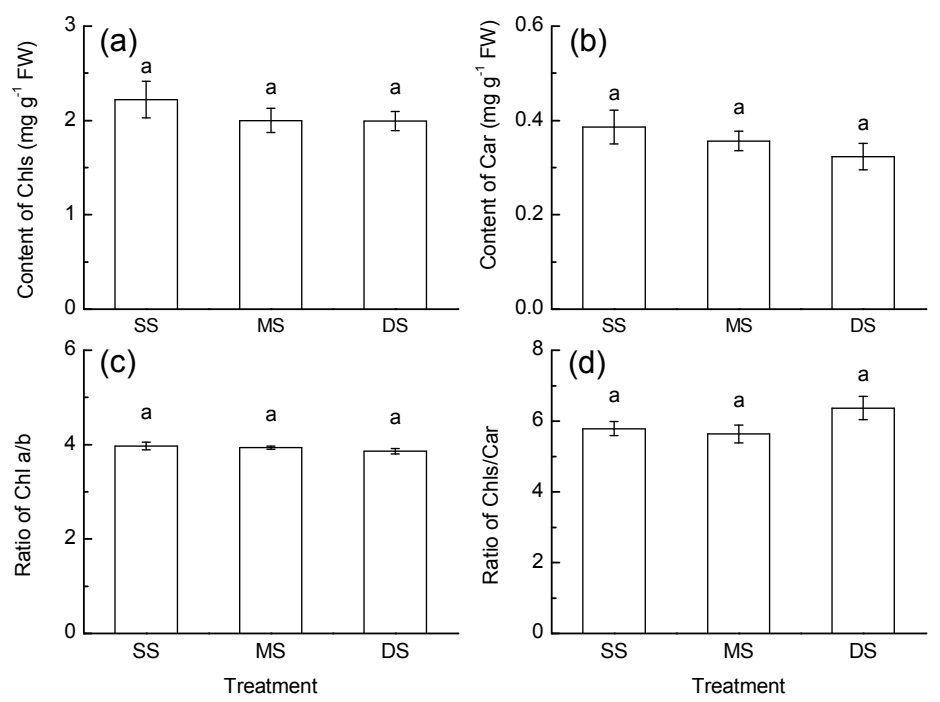

Figure 3. Chlorophylls (Chls) content (a), carotenoid (Car) content (b), ratio of chlorophyll a/b (Chl a/b) (c) and ratio of chlorophylls/carotenoid (Chls/Car) (d) of S. matsudana under shallow submergence (SS), moderate submergence (MS) and deep submergence (DS) treatment in the hydro-fluctuation zone of the TGDR. Different letters on each bar represent significant difference among treatments at the 0.05 level. Values are means \pm standard error $(n=9)$.

\subsection{Growth Response}

The mean DBH and tree height of S. matsudana were significantly decreased in MS $(p<0.001$, $p=0.04$, respectively) and DS (both $p<0.001$ ) as compared to that in SS, with a $39 \%$ and $33 \%$ decrease, as well as $43 \%$ and $44 \%$ decrease, respectively (Figure $4 a, b$ ). There was no significant difference to be detected in crown area under all treatment $(p>0.05)$ (Figure $4 c)$. However, primary branch number was significantly increased as submergence increased $(p<0.001)$ (Figure $4 \mathrm{~d})$. RDGR and RHGR of $S$. matsudana was significantly decreased in MS ( $p=0.001,0.032$, respectively) and DS ( $p<0.001$, $p=0.002$, respectively) as compared to that in SS, respectively, while there was no significant difference between MS and DS $(p>0.05)$ (Figure $5 a, b)$.
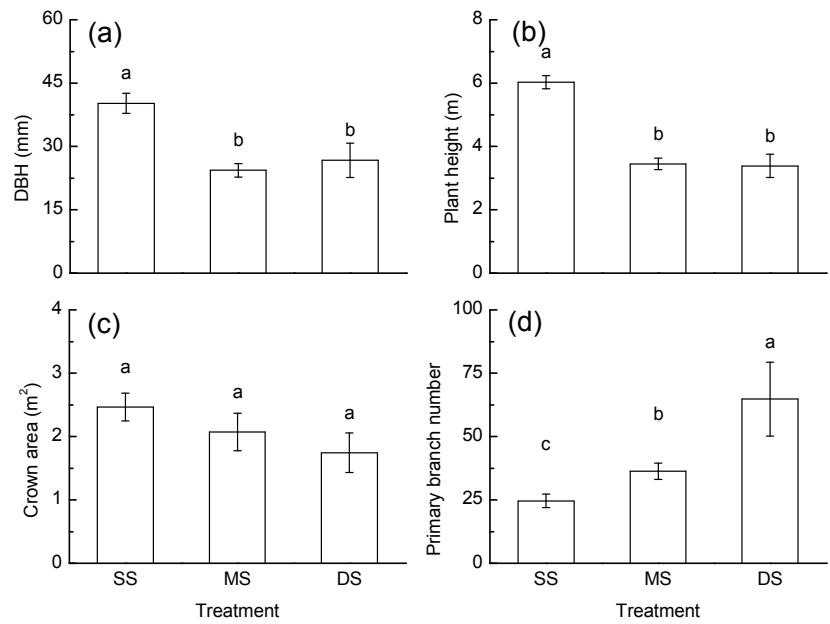

Figure 4. Diameter at breast height (DBH) (a), tree height (b), crown area (c) and primary branch number (d) of S. matsudana under shallow submergence (SS), moderate submergence (MS) and deep submergence (DS) treatment in the hydro-fluctuation zone of the TGDR. Different letters on each bar represent significant difference among treatments at the 0.05 level. Values are means \pm standard error $(n=9)$. 

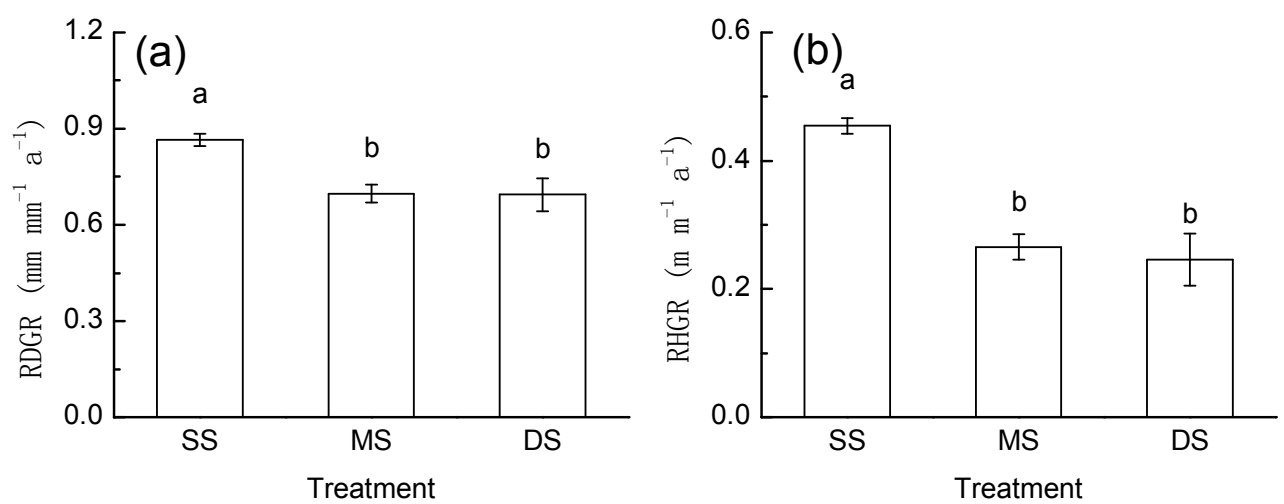

Figure 5. Relative diameter growth rate (RDGR) (a) and relative height growth rate (RHGR) (b) of S. matsudana under shallow submergence (SS), moderate submergence (MS) and deep submergence (DS) treatment in the hydro-fluctuation zone of the TGDR. Different letters on each bar represent significant difference among treatments at the 0.05 level. Values are means \pm standard error $(n=9)$.

\subsection{Correlation}

Based on Pearson correlations analysis, there were significant correlations between $P_{n}$ and growth indices, except for primary branch number in S. matsudana. WUEi and Ls also exhibited a significant correlation with tree height (Table 2).

Table 2. Correlations between gas exchange parameters and growth indexes for S. matsudana saplings $(n=27)$.

\begin{tabular}{ccccc}
\hline Indexes & DBH $^{\ddagger}$ & TH & CA & PBN \\
\hline$P_{n}$ & $0.72^{* * *}$ & $0.588^{* *}$ & $0.49^{* *}$ & -0.291 \\
$g_{s}$ & 0.158 & -0.048 & 0.298 & 0.095 \\
WUEi & 0.312 & $0.418^{*}$ & 0.028 & -0.301 \\
Ls & 0.377 & $0.46^{*}$ & 0.095 & -0.352 \\
\hline
\end{tabular}

$\ddagger$ Diameter at breast height (DBH), tree height $(\mathrm{TH})$, crown area (CA), primary branch number (PBN), net photosynthetic rate $\left(P_{n}\right)$, stomata conductance $\left(g_{s}\right)$, intrinsic water use efficiency (WUEi) and limiting value of stomata (Ls). ${ }^{*} p<0.05,{ }^{* *} p<0.01,{ }^{* * *} p<0.001$.

\section{Discussion}

Selection of submergence-tolerant plant species is the foundation of artificial vegetation restoration of the hydro-fluctuation zone in the TGDR region. With the hydro-fluctuation zone submerged and exposed, plant habitat in this region will be greatly changed. Although plants could endure energy deficit caused by long-term submergence, physiological difficulties like membrane damage and cell death caused by free oxygen radical after rapid exposure to air may affect plant survival $[46,47]$. Therefore, when assessing plant adaptation, both water tolerance and regrowth after water draining should be considered [25]. Moreover, multiple cycles of water level change also need to be considered when assessing plant submergence tolerance.

\subsection{Photosynthesis Response to Periodic Submergence}

Photosynthetic recovery after submergence will help the plants store more carbohydrates [48]. This will provide more energy for plants to resist the next submergence [49]. Efficient photosynthetic acclimation is also important in post-submergence growth recovery due to growth inhibition caused by photo-oxidative damage that results from high irradiance [50]. Thus, the recovery of photosynthesis is a criterion in evaluating the flooding tolerance of plants. Submergence intensity and duration will affect photosynthetic recovery of plant after submergence [51]. Furthermore, plant resistance to submergence will also affect the recovery. In this study, photosynthetic parameters of $S$. matsudana 
under moderate submergence (MS) recovered to the control level. Salix nigra showed the same results under periodic flooding treatment [32]. Other plants, like Styrax pohlii [52], Melaleuca alternifolia [53] and Populus deltoides [54], also restored their photosynthesis to control level after the water was drained. The maintenances of photosynthetic parameters suggested that $S$. matsudana had strong resistance to periodic moderate submergence. In the field, S. matsudana could quickly regenerate new leaves at middle elevation after exposure.

Photosynthetic decline in response to deep submergence is common in many plants, even in some tolerant species, because deep submergence involves energy deficit due to low oxygen and light [55]. Zhao et al. [56] reported that after flooding $75 \mathrm{~d}, P_{n}$ in Salix integra cv. Hongpi seedlings was only $54 \%$ of the control. S. nigra also showed a significant decrease in $P_{n}$ in flooding condition [32]. The photosynthetic reduction was mainly caused by stomatal closure and non-stomatal (metabolic) inhibition [57]. In the present study, the $P_{n}$ and Ls decreased, while $C_{i}$ increased (data not shown) in DS. Thus, non-stomata limitation was one of the factors that caused the reduction in $P_{n}$ of $S$. matsudana in response to long-term deep submergence [57]. The reason for the lack of correspondence between $g_{s}$ and $P_{n}$ in DS in our present study might be attributed to the damage of the structure and function of the photosystem, and the decrease of photosynthetic activity of the leaf mesophyll cells [57]. Previous study of Herrera et al. [58] on Campsiandra laurifolia also found a lack of correspondence between $g_{s}$ and $P_{n}$. This result suggested that high intensity and long duration of submergence had affected the physiology of S. matsudana. Fan et al. [5] summarized the studies on plant recovery after submergence of the hydro-fluctuation zone of the TGDR region, and found that plant recovery after submergence had significant relation to submergence time and depth. In our present study, the decreased net photosynthetic rate of $S$. matsudana was consistent with this result. This result may be caused by decreased expression of photosynthetic genes like oxygen-evolving complex, large subunit of ribulose-1,5-bisphosphate carboxylase/oxygenase and ferredoxin [33].

In photosynthesis, chlorophyll $\mathrm{a}$ and $\mathrm{b}$ are predominantly bound to the photosynthetic reaction center and the light-harvesting chlorophyll a/b protein complex, respectively [59]. Therefore, leaf chlorophyll content can affect the photosynthesis of plants, then affect the accumulation of plant dry matter. Carotenoid can be used as antioxidant to scavenge oxygen radical and protect chlorophyll [60,61]. Former research showed that submergence generally caused chlorophyll degradation and a change in $\mathrm{Chl} \mathrm{a/b} \mathrm{[56].} \mathrm{A} \mathrm{field} \mathrm{study} \mathrm{conducted} \mathrm{in} \mathrm{the} \mathrm{TGDR} \mathrm{on} \mathrm{Salix} \mathrm{variegata}$ also found the same results $[62,63]$. In this study, pigment contents of $S$. matsudana had no significant difference among the three submergence treatments. These results suggested that $S$. matsudana could recover its pigment content after submergence. This is one of the reasons for photosynthesis recovery.

\subsection{Growth Response to Periodic Submergence}

The survival and regrowth of plants after submergence is most important in assessing plant tolerance to submergence [64]. Frequent floods may increase tree mortality [65]. Reduced plant survival and growth in response to flooding is common among many species $[30,36,66]$. An investigation conducted in the TGDR found that S. matsudana and $S$. variegate were distributed in the water level fluctuation zone and they could endure 210 days of $5 \mathrm{~m}$-deep submergence with a survival rate of $13 \%$ and $47 \%$, respectively [62]. However, the survival rates of S. matsudana in high and moderate elevation and low elevation of the present study were $100 \%$ and $80 \%$, respectively, after experiencing three years of water level changes, suggesting that this species adapted to the stressful condition of TGDR. It is stated that energy deficit, caused by respiration inhibition in oxygen deprivation, is one of the most severe problems for plants under flooding [67]. Under anoxia condition, synthesis of anaerobic protein will protect the membrane structure of mitochondria [68] to maintain energy supply. Besides, some woody plants slow down metabolism upon submergence to preserve starch reserves in the tap-root and to maintain the capacity of regrowth on de-submergence [69]. These strategies may be the reasons for the high survival rate of $S$. matsudana. 
The survival and growth of a plant is a comprehensive response of habitat adaptation $[63,70,71]$. The sustainable growth of plants in the hydro-fluctuation zone of the TGDR is very important in this region. In the present study, the mean of DBH and tree height of S. matsudana in MS and DS were significantly lower than that in SS. In the TGDR, plants are in a quiescent state with no shoot elongation during winter submergence [55]. Their biomass production period is mainly in the exposure duration. Since the exposure duration of MS was shorter than SS, the growth of S. matsudana was significantly inhibited by submergence despite the recovered $P_{n}$ of MS. In contrast to the recovery of $P_{n}$ of $S$. matsudana in MS, $P_{n}$ of $S$. matsudana in DS was significantly lower. Moreover, the exposure duration of DS was shorter than MS. These caused a lower growth of S. matsudana in DS. Li et al. [72] found that the recovery growth of $D$. chinense seedlings decreased as submergence duration increased. A decreased growth of Salix triandroides was also shown in a submergence simulation study [73]. Thus, the slow recovery rate might be another reason for its lower growth. The primary branch number was significantly increased with submergence increase. In the former research, Salix species were dominated in the riparian zone due to tolerance to prolonged flooding through their high regenerative capacity [37]. In the present study, the high increased primary branch number confirmed its high regenerative capacity. After water recession, plants tend to grow more branches and leaves to gain more energy to meet the high energy expenditure under deep submergence [74]. However, the crown area was not affected by submergence. The reason for this phenomenon was that the most branches of last year died in submergence, and several new short branches grew on the trunk after exposure. With submergence increase, this phenomenon was more obvious. Former research found that Taxodium distichum as a high flooding-tolerant species also showed dieback in some apical shoots and no leaf expansion took place in submergence condition, moreover, dieback after water withdrawal became more serious [66]. In S. matsudana, shoot dieback also appeared under submergence. Higher re-sprouting capacity of Salix will cost much energy, leading to short branch elongation.

Relative growth rate is another factor reflecting the adaptation of a plant. In this study, the relative DBH and tree height growth rates were positive, suggesting that $S$. matsudana could maintain a constant growth under three years of periodic submergence. The relative DBH and tree height growth rates under MS and DS were significantly lower than SS, indicating that submergence had inhibited the growth of this plant. Despite the leaf abscission and part branch death of S. matsudana under submergence, the growth rate of this plant is sufficient to maintain its survival and growth in the hydro-fluctuation zone of the TGDR.

\section{Conclusions}

The photosynthesis and growth recovery of $S$. matsudana after submergence were various due to the difference of submergence depth and duration of each elevation. The pigment content of this plant after exposure recovered to control level, but the photosynthesis and growth were significantly affected by long-term deep submergence. Combined with the relative DBH and tree height growth, S. matsudana could adapt to the hydro-fluctuation zone of the TGDR and be applied to artificial vegetation restoration of this region.

Acknowledgments: The authors acknowledge financial support from the Chongqing Municipality Key Forestry Research Project (No. Yulinkeyan 2016-8), the Project of Natural Forest Protection Center of the State Forestry Administration (No. 2016001), China Central Finance Forestry Extension Program (Yulinketui 2014-10) and Chongqing Postgraduate Research and Innovation Project (No. CYB16066).

Author Contributions: C.W. analyzed the data and wrote the paper; C.W. and Y.X. performed the experiments; C.L. conceived and designed the experiments. The remaining authors contributed to refining the ideas, carrying out additional analyses and finalizing this paper.

Conflicts of Interest: The authors declare no conflict of interest. 


\section{References}

1. Xu, X.B.; Tan, Y.; Yang, G.S.; Li, H.P.; Su, W.Z. Soil erosion in the Three Gorges Reservoir area. Soil Res. 2011, 49, 212-222. [CrossRef]

2. Ye, C.; Li, S.Y.; Zhang, Y.R.; Zhang, Q.F. Assessing soil heavy metal pollution in the water-level-fluctuation zone of the Three Gorges Reservoir, China. J. Hazard. Mater. 2011, 191, 366-372. [CrossRef] [PubMed]

3. Ma, L.; Yuan, J.; Sun, X.; Zhang, M. Spatial distribution and release of nitrogen in soils in the water fluctuation zone of the Three Gorges Reservoir. J. Food Agric. Environ. 2012, 10, 787-791.

4. Subklew, G.; Ulrich, J.; Fürst, L.; Höltkemeier, A. Environmental impacts of the Yangtze Three Gorges project: An overview of the Chinese-German research cooperation. J. Earth Sci. 2010, 21, 817-823. [CrossRef]

5. Fan, D.Y.; Xiong, G.M.; Zhang, A.Y.; Liu, X.; Xie, Z.Q.; Li, Z.J. Effect of water-lever regulation on species selection for ecological restoration practice in the water-level fluctuation zone of Three Gorges Reservoir. Chin. J. Plant Ecol. 2015, 39, 416-432. [CrossRef]

6. Zhang, M.; Chen, F.; Wu, Y.; Ma, Y.; Guan, S.; Huang, Y. Characteristics of the soil seed bank of planted and natural restored draw-down zones in the Three Gorges Reservoir region. Ecol. Eng. 2017, 103, 127-133. [CrossRef]

7. Langer, E.R.; Steward, G.A.; Kimberley, M.O. Vegetation structure, composition and effect of pine plantation harvesting on riparian buffers in New Zealand. For. Ecol. Manag. 2008, 256, 949-957. [CrossRef]

8. Chazdon, R.L. Beyond deforestation: Restoring forests and ecosystem services on degraded lands. Science 2008, 320, 1458-1460. [CrossRef] [PubMed]

9. Jones, P.D.; Edwards, S.L.; Demarais, S.; Ezell, A.W. Vegetation community responses to different establishment regimes in loblolly pine (Pinus taeda) plantations in southern MS, USA. For. Ecol. Manag. 2009, 257, 553-560. [CrossRef]

10. Azza, N.; Denny, P.; van de Koppel, J. Floating mats: Their occurrence and influence on shoreline distribution of emergent vegetation. Freshw. Biol. 2006, 51, 1286-1297. [CrossRef]

11. Deletic, A. Sediment transport in urban runoff over grassed areas. J. Hydrol. 2005, 301, 108-122. [CrossRef]

12. Bardgett, R.D.; van der Wal, R.; Jonsdottir, I.S.; Quirk, H.; Dutton, S. Temporal variability in plant and soil nitrogen pools in a High-Arctic ecosystem. Soil Biol. Biochem. 2007, 39, 2129-2137. [CrossRef]

13. Dunchemin, M.; Hogue, R. Reduction in agricultural non-point source pollution in the first year following establishment of an integrated grass/tree filter strip system in Southern Quebec (Canada). Agric. Ecosyst. Environ. 2009, 131, 85-97. [CrossRef]

14. Mudd, S.M.; Alpaos, A.D.; Morris, J.T. How does vegetation affect sedimentation on tidal marshes? Investigating particle capture and hydrodynamic controls on biologically mediated sedimentation. J. Geophys. Res. 2010, 115, F03029. [CrossRef]

15. Ye, C.; Cheng, X.L.; Zhang, Y.L.; Wang, Z.X.; Zhang, Q.F. Soil nitrogen dynamics following short-term revegetation in the water level fluctuation zone of the Three Gorges Reservoir, China. Ecol. Eng. 2012, 38, 37-44. [CrossRef]

16. Li, C.X.; Wei, H.; Geng, Y.H.; Schneider, R. Effects of submergence on photosynthesis and growth of Pterocarya stenoptera (Chinese wingnut) seedlings in the recently-created Three Gorges Reservoir Region of China. Wetl. Ecol. Manag. 2010, 18, 485-494. [CrossRef]

17. Wang, Y.; Liu, Y.F.; Liu, S.B.; Huang, H.W. Vegetation reconstruction in the water-level-fluctuation zone of the Three Gorges Reservoir. Chin. Bull. Bot. 2005, 22, 513-522.

18. Li, C.X.; Zhong, Z.C.; Liu, Y. Effect of soil water change on photosynthetic characteristics of Taxodium distichum seedlings in the hydro-fluctuation belt of the Three Gorges Reservoir Area. Acta Ecol. Sin. 2005, 25, $23-28$. [CrossRef]

19. Li, C.X.; Zhong, Z.C.; Geng, Y.H.; Schneider, R. Comparative studies on physiological and biochemical adaptation of Taxodium distichum and Taxodium ascendens seedlings to different soil water regimes. Plant Soil 2010, 329, 481-494. [CrossRef]

20. Lei, S.T.; Zeng, B.; Xu, S.J.; Su, X.L. Membrane responses of Salix variegata and Cinnamomum camphora to complete submergence in the Three Gorges Reservoir Region. Acta Ecol. Sin. 2012, 32, 227-231. [CrossRef]

21. Kawano, N.; Ella, E.; Ito, O.; Yamauchi, Y.; Tanaka, K. Metabolic changes in rice seedlings with different submergence tolerance after desubmergence. Environ. Exp. Bot. 2002, 47, 195-203. [CrossRef] 
22. Blokhina, O.; Virolainen, E.; Fagerstedt, K.V. Antioxidants, oxidative damage and oxygen deprivation stress: A review. Ann. Bot. 2003, 91, 179-194. [CrossRef] [PubMed]

23. Crawford, R.M.M. Seasonal differences in plant responses to flooding and anoxia. Can. J. Bot. 2003, 81, 1224-1226. [CrossRef]

24. Panda, D.; Sarkar, R.K.; Sharma, S.G. Chlorophyll fluorescence parameters, $\mathrm{CO}_{2}$, photosynthetic rate and regeneration capacity as a result of complete submergence and subsequent re-emergence in rice (Oryza sativa L.). Aquat. Bot. 2008, 88, 127-133. [CrossRef]

25. Striker, G.G. Time is on our side: The importance of considering a recovery period when assessing flooding tolerance in plants. Ecol. Res. 2012, 27, 983-987. [CrossRef]

26. Colmer, T.D. Long-distance transport of gases in plants: A perspective on internal aeration and radial oxygen loss from roots. Plant Cell Environ. 2003, 26, 17-36. [CrossRef]

27. Schaff, S.D.; Pezeshki, S.R.; Shields, F.D., Jr. Effects of soil conditions on survival and growth of black willow cuttings. Environ. Manag. 2003, 31, 748-763. [CrossRef] [PubMed]

28. Kuzovkina, Y.A.; Quigley, M.F. Willows beyond wetlands: Uses for Salix L. species for environmental projects. Water Air Soil Pollut. 2005, 162, 183-204. [CrossRef]

29. Tallenthalsell, N.G.; Walker, L.R. Responses of Salix gooddingii and Tamarix ramosissima to flooding. Wetlands 2002, 22, 776-785. [CrossRef]

30. Higa, M.; Moriyama, T.; Ishikawa, S. Effects of complete submergence on seedling growth and survival of five riparian tree species in the warm-temperate regions of Japan. J. For. Res. 2012, 17, 129-136. [CrossRef]

31. Kuzovkina, Y.A.; Knee, M.; Quigley, M.F. Effects of soil compaction and flooding on the growth of 12 willow (Salix L.) species. J. Environ. Hortic. 2004, 22, 155-160.

32. Li, S.; Pezeshki, S.R.; Goodwin, S.; Shields, F.D., Jr. Physiological responses of black willow (Salix nigra) cuttings to a range of soil moisture regimes. Photosynthetica 2004, 42, 585-590. [CrossRef]

33. Li, S.; Goodwin, S.; Pezeshki, S.R. Photosynthetic gene expression in black willow under various soil moisture regimes. Biol. Plant. 2007, 51, 593-596. [CrossRef]

34. Waldhoff, D. Leaf structure in trees of central Amazonian floodplain forests (Brazil). Amazoniana 2003, $17,451-469$.

35. Li, S.; Pezeshki, S.R.; Shields, F.D., Jr. Partial flooding enhances aeration in adventitious roots of black willow (Salix nigra) cuttings. J. Plant Physiol. 2006, 163, 619-628. [CrossRef] [PubMed]

36. Nakai, A.; Kisanuki, H. Stress responses of Salix gracilistyla, and Salix subfragilis cuttings to repeated flooding and drought. J. For. Res. 2011, 16, 465-472. [CrossRef]

37. Markus-Michalczyk, H.; Hanelt, D.; Kai, J. Effects of tidal flooding on juvenile willows. Estuar. Coasts 2016, 39, 1-9. [CrossRef]

38. Zhong, Y.; Liu, Z.X.; Qin, H.W.; Xiong, Y.; Xiang, L.X.; Liu, R.; Yang, Y.; Ma, R. Effects of winter submergence and waterlogging on growth and recovery growth of Salix babylonica. J. South. Agric. 2013, 44, 275-279. [CrossRef]

39. Zhang, S.S.; Li, R.N.; Wang, W.; Lu, W.Y.; Ren, Y.; Fu, S.L. Tree species selection in the riparian zone of Meishan reservoir. J. Anhui Agric. Univ. 2015, 42, 357-362.

40. Tang, J.L.; Wang, T.; Zhu, B.; Zhao, P.; Xiao, Y.; Wang, R. Tempo-spatial analysis of water quality in tributary bays of the Three Gorges Reservoir region (China). Environ. Sci. Pollut. Res. 2015, 22, 16709-16720. [CrossRef] [PubMed]

41. Pezeshki, S.R.; Li, S.W.; Shields, F.D., Jr.; Martina, L.T. Factors governing survival of black willow (Salix nigra) cuttings in a streambank restoration project. Ecol. Eng. 2007, 29, 56-65. [CrossRef]

42. Berry, J.A.; Downton, W.J.S. Environmental regulation of photosynthesis. In Photosynthesis; Govind, J., Ed.; Academic Press: New York, NY, USA, 1982; Volume 2, pp. 263-343. [CrossRef]

43. Li, C.X.; Geng, Y.H.; Ye, B.; Schneider, R. Response of baldcypress and pondcypress seedlings to multiple stresses and reforestation implication for riparian zone of the Three Gorges Reservoir region of China. Sci. Silv. Sin. 2010, 46, 144-152. [CrossRef]

44. Lichtenthaler, H.K.; Wellburn, A.R. Determinations of total carotenoids and chlorophylls $a$ and $b$ of leaf extracts in different solvents. Biochem. Soc. Trans. 1983, 11, 591-592. [CrossRef]

45. Masaka, K.; Sato, H.; Kon, H.; Fukuchi, M. Demographic and height growth response of native broad-leaved deciduous tree saplings to overhead canopy release in a coastal Pinus thunbergii forest in Hokkaido, northern Japan. J. For. Res. 2012, 17, 421-431. [CrossRef] 
46. Colmer, T.D.; Voesenek, L.A.C.J. Flooding tolerance: Suites of plant traits in variable environments. Funct. Plant Biol. 2009, 36, 665-681. [CrossRef]

47. Gu, X.; Li, Z.Q.; Jiang, C.D.; Shi, L.; Zhang, H.J.; Xing, Q. Effects of submergence and subsequent re-emergence on photosynthetic characteristics and photoinhibition in Echinodorus amazonicus seedlings. Acta Ecol. Sin. 2009, 29, 6466-6474.

48. Sharma, P.; Asaeda, T.; Kalibbala, M.; Fujino, T. Morphology, growth and carbohydrate storage of the plant Typha angustifolia at different water depths. Chem. Ecol. 2008, 24, 133-145. [CrossRef]

49. Sharma, P.; Asaeda, T.; Fujino, T. Effect of water depth on the rhizome dynamics of Typha angustifolia. Wetl. Ecol. Manag. 2008, 16, 43-49. [CrossRef]

50. Luo, F.L.; Nagel, K.A.; Zeng, B.; Schurr, U.; Matsubara, S. Photosynthetic acclimation is important for post-submergence recovery of photosynthesis and growth in two riparian species. Ann. Bot. 2009, 104, 1435-1444. [CrossRef] [PubMed]

51. Glenz, C.; Schlaepfer, R.; Iorgulescu, I.; Kienast, F. Flooding tolerance of central European tree and shrub species. For. Ecol. Manag. 2006, 235, 1-13. [CrossRef]

52. Kissmann, C.; Veiga, E.B.D.; Eichemberg, M.T.; Habermann, G. Morphological effects of flooding on Styrax pohlii and the dynamics of physiological responses during flooding and post-flooding conditions. Aquat. Bot. 2014, 119, 7-14. [CrossRef]

53. Jing, Y.X.; Li, G.L.; Gu, B.H.; Yang, D.J.; Xiao, L.; Liu, R.X.; Peng, C.L. Leaf gas exchange, chlorophyll fluorescence and growth responses of Melaleuca alternifolia, seedlings to flooding and subsequent recovery. Photosynthetica 2009, 47, 595-601. [CrossRef]

54. Rodríguez, M.E.; Achinelli, F.G.; Luquez, V.M.C. Leaf traits related to productivity in Populus deltoides during the post-flooding period. Trees 2015, 29, 953-960. [CrossRef]

55. Parolin, P. Submerged in darkness: Adaptations to prolonged submergence by woody species of the Amazonian floodplains. Ann. Bot. 2009, 103, 359-376. [CrossRef] [PubMed]

56. Zhao, H.F.; Zhao, Y.; Zhang, C.; Tao, X.; Xu, X.N. Growth, leaf gas exchange, and chlorophyll fluorescence responses of two cultivars of Salix integra Thunb. to waterlogging stress. J. Agric. Sci. Technol. 2014, 16, 137-149.

57. Farquhar, G.D.; Sharkey, T.D. Stomatal conductance and photosynthesis. Annu. Rev. Plant Physiol. 1982, 33, 317-345. [CrossRef]

58. Herrera, A.; Tezara, W.; Marín, O.; Rengifo, E. Stomatal and non-stomatal limitations of photosynthesis in trees of a tropical seasonally flooded forest. Physiol. Plant 2008, 134, 41-48. [CrossRef] [PubMed]

59. Larcher, W. Physiological Plant Ecology, 4th ed.; Springer: Berlin, Germany, 2003.

60. Tracewell, C.A.; Vrettos, J.S.; Bautista, J.A.; Frank, H.A.; Brudvig, G.W. Carotenoid photooxidation in photosystem II. Arch. Biochem. Biophys. 2001, 385, 61-69. [CrossRef] [PubMed]

61. Caldwell, C.R.; Britz, S.J. Effect of supplemental ultraviolet radiation on the carotenoid and chlorophyll composition of green-house leaf lettuce (Lactuca sativa L.) cultivars. J. Food Compos. Anal. 2006, 19, 637-644. [CrossRef]

62. Yang, F.; Wang, Y.; Chan, Z. Perspectives on screening winter-flood-tolerant woody species in the riparian protection forests of the Three Gorges Reservoir. PLoS ONE 2014, 9, e108725. [CrossRef] [PubMed]

63. Miao, L.F.; Xiao, F.J.; Xu, W.; Yang, F. Reconstruction of wetland zones: Physiological and biochemical responses of Salix variegata to winter submergence-a case study from water level fluctuation zone of the Three Gorges Reservoir. Pol. J. Ecol. 2016, 64, 45-52. [CrossRef]

64. Mommer, L.; Lenssen, J.P.M.; Huber, H.; Visser, E.J.W.; Kroon, H.D. Ecophysiological determinants of plant performance under flooding: A comparative study of seven plant families. J. Ecol. 2006, 94, 1117-1129. [CrossRef]

65. Berthelot, J.S.; Saint-Laurent, D.; Gervais-Beaulac, V.; Présent, A. A comparison of the composition and diversity of tree populations along a hydrological gradient in floodplains (southern Québec, Canada). Forests 2015, 6, 929-956. [CrossRef]

66. Iwanaga, F.; Tanaka, K.; Nakazato, I.; Yamamoto, F. Effects of submergence on growth and survival of saplings of three wetland trees differing in adaptive mechanisms for flood tolerance. For. Syst. 2015, 24, 1-9. [CrossRef]

67. Voesenek, L.A.C.J.; Colmer, T.D.; Pierik, R.; Millenaar, F.F.; Peeters, A.J.M. How plants cope with complete submergence. New Phytol. 2006, 170, 213-226. [CrossRef] [PubMed] 
68. Vartapetian, B.B.; Generosova, I.P.; Zakhmylova, N.A.; Snkhchyan, A.G. Demonstration of plant adaptation syndrome in plants and possible molecular mechanisms of its realization under conditions of anaerobic stress. Russ. J. Plant Physiol. 2006, 53, 747-755. [CrossRef]

69. Parolin, P. Submergence tolerance vs. escape from submergence: Two strategies of seedling establishment in Amazonian floodplains. Environ. Exp. Bot. 2002, 48, 177-186. [CrossRef]

70. Tang, Z.C.; Kozlowski, T.T. Responses of Pinus banksiana and Pinus resinosa seedlings to flooding. Can. J. For. Res. 1983, 13, 633-639. [CrossRef]

71. Gibbs, J.; Greenway, H. Mechanism of anoxia tolerance in plants. I. Growth, survival and anaerobic catabolism. Funct. Plant Biol. 2003, 30, 1-47. [CrossRef]

72. Li, X.L.; Luan, C.Y.; Yang, J.; Chen, F.J. Survival and recovery growth of riparian plant Distylium chinense seedlings to complete submergence in the Three Gorges Reservoir region. Procedia Eng. 2012, 28, 85-94. [CrossRef]

73. Ding, X.; Zou, J.; Li, Y.; Yao, X.; Zou, D.; Zhang, C.; Yang, N.; Niu, Y.; Bian, H.; Deng, J.; et al. Acclimation of Salix triandroides, cuttings to incomplete submergence is reduced by low light. Aquat. Ecol. 2017, 51, 321-330. [CrossRef]

74. Dionigi, C.P.; Mendelssohn, I.A.; Sullivan, V.I. Effects of soil waterlogging on the energy status and distribution of Salix nigra and S. Exigua (Salicaceae) in the Atchafalaya river basin of Louisiana. Am. J. Bot. 1985, 72, 109-119. [CrossRef]

(C) 2017 by the authors. Licensee MDPI, Basel, Switzerland. This article is an open access article distributed under the terms and conditions of the Creative Commons Attribution (CC BY) license (http://creativecommons.org/licenses/by/4.0/). 